\title{
Bovine in vitro embryo production protocol: does it really influence embryo cryotolerance?*
}

\author{
Protocolo de produção in vitro de embriões bovinos: \\ este realmente influencia a criotolerância dos embriões?

\begin{abstract}
Arnaldo Diniz Vieira, Fabiana Forell, Cristiano Feltrin, Lucila Carboneiro dos Santos \& José Luiz Rodrigues
\end{abstract}

\begin{abstract}
The protocol of in vitro production (IVP) of bovine embryos is one of the critical factors determining embryo viability after cryopreservation. In this study were used two differents protocols to produce IVP bovine embryos, with variations in protein source, oocyte/zygote density per media volume, with the aim to determine the in vitro and in vivo embryo survival after vitrification using hand-pulled glass micropipettes. Expanded blastocysts (D7) were morphologically selected by size ( $\geq 180 \mu \mathrm{m})$ and osmotic behavior before they were randomly allocated to sub-groups by protocol: non-vitrified embryos (control; C) and vitrified embryos (V). For the evaluation of the in vitro survival, control embryos and a group of warmed vitrified embryos were in vitro-cultured (IVC) for $72 \mathrm{~h}$. Re-expansion rates of warmed embryos at $24 \mathrm{~h}$ of IVC were $94.8 \%$ and $93.2 \%$ for Protocols 1 and 2, respectively. Hatching rates at $72 \mathrm{~h}$ of IVC of embryos from Protocol $1(\mathrm{C}=80 \%$ and $\mathrm{V}=75.8 \%)$ tended to be higher $\left(\mathrm{P}=0.0561, \mathrm{Chi}^{2}\right.$ test $)$ than those from Protocol $2(\mathrm{C}=67.2 \%$ and $\mathrm{V}=59.3 \%)$. For the evaluation of in vivo survival, 21 vitrified embryos per protocol were singly non-surgically transferred to synchronized recipients $(n=42)$ after the in-straw cryoprotectant dilution, resulting in 4 (19\%) pregnancies per group on Day 60 of gestation. In conclusion, despite a lower variation on in vitro embryo development between both IVP protocols, the use of different protocols under the same laboratory conditions did not afect the in vitro and in vivo embryo viability after vitrification into hand-pulled glass micropipettes.
\end{abstract}

Key words: vitrification, embryo survival, direct transfer.

\section{RESUMO}

O protocolo de produção in vitro (PIV) de embriões bovinos é um dos fatores críticos na determinação da viabilidade dos embriões após a criopreservação. Neste estudo foram utilizados dois protocolos de PIV com variações na fonte protéica, relação oócito/zigoto por volume de meio e condições de cultivo objetivando determinar a sobrevivência in vitro e in vivo dos embriões após vitrificação dentro de micropipetas de vidro estiradas à mão. Blastocistos expandidos (D7) oriundos dos dois protocolos foram selecionados morfologicamente pelo tamanho $(\geq 180 \mu \mathrm{m})$ e comportamento osmótico antes de serem aleatoriamente distribuídos em dois sub-grupos: embriões não vitrificados (controle; C) e embriões vitrificados (V). Para a avaliação da sobrevivência in vitro, os embriões controle e grupos de embriões reaquecidos foram cultivados in vitro (CIV) por $72 \mathrm{~h}$. As taxas de re-expansão após $24 \mathrm{~h}$ de CIV dos embriões re-aquecidos foram 94,8\% e 93,2\% para os Protocolos 1 e 2, respectivamente. As taxas de eclosão (72 h) dos embriões do Protocolo $1(\mathrm{C}=80 \%$ e V =75,8\%) tenderam a ser maiores do que as do Protocolo $2(\mathrm{C}=67,2 \%$ e V = 59,3\%). Para a avaliação da sobrevivência in vivo, após a remoção dos crioprotetores dentro da palheta, 21 embriões vitrificados de cada protocolo foram transferidos por via transcervical para receptoras síncronas ( $\mathrm{n}=42$ ). Aos 60 dias de gestação, foram diagnosticadas por palpação retal 4 (19\%) prenhezes em cada grupo. Em conclusão, apesar de uma pequena variação na taxa de desenvolvimento in vitro entre os diferentes protocolos, os resultados de sobrevivência in vitro e in vivo demonstraram que, sob condições laboratoriais similares, os diferentes protocolos não afetaram a viabilidade dos embriões após a vitrificação em micropipetas de vidro estiradas à mão.

Descritores: vitrificação, sobrevivência embrionária, transferência direta.

*This manuscript is based on thesis submitted by the senior author in partial fulfillment of requirements for the degree of Doctor in Veterinary Science, Graduate Program in Veterinary Sciences, Faculdade de Veterinária (FaVet), Universidade Federal do Rio Grande do Sul (UFRGS). Embryology and Biotechnology of Reproduction Laboratory, FaVet/UFRGS, Porto Alegre, Brazil. CORRESPONDENCE: A.D. Vieira [vieira_ad@yahoo.com.br ; Fax: + 555133167305$]$. 


\section{INTRODUCTION}

Bovine embryos generated by distinct in vitro production (IVP) systems can respond differently to cryopreservation approaches [1,5,36]. Consequently, it is difficult to compare data from different laboratories due to the diverse experimental and enviromental conditions. This variability may be determined by a multitude of factors such as water quality [21,22], type of oil overlay [36], oocyte quality [15,28], and culture systems $[18,19,27]$, among others.

The embryo cryotolerance largely depends on the IVP conditions, which is a determinant of embryo quality, but cryosurvival can also be improved by adjusting or improving the cryopreservation procedures. The OPS technology has been proven successful not only for the vitrification of bovine immature oocytes and IVP embryos [37], but also in combination with the in-straw cryoprotectant dilution method [16,34]. In addition, the rapid cooling and warming rates in the OPS system may be accompanied by variations in the vitrification container $[3,20]$. In this view, the use of glass micropipettes may offer physical advantages over plastic straws. However, methodologies that allow the direct transfer of the embryos after the in-straw cryoprotectant dilution [16,34] have not been tested with glass micropipettes.

The aim of this study was to determine the influence of two IVP protocols on the in vitro development and in vitro and in vivo survival of bovine expanded blastocysts after vitrification into hand-pulled glass micropipettes.

\section{MATERIALS AND METHODS}

\section{Source of cumulus-oocyte complexes}

Bovine ovaries were transported to the laboratory in PBS at $24-32^{\circ} \mathrm{C}$ upon slaughter. Cumulus- oocyte complexes (COCs) isolated by ovary slicing were evaluated under a stereomicroscope and only COCs with evenly granulated cytoplasm and surrounded by a compact and dense cumulus cell layer were used in two distinct IVP protocols.

\section{In vitro Embryo Production Protocols}

The IVP systems used in this study were based on established procedures by Rodrigues et al. [29] and Vieira et al., [37], for Protocols 1 and 2, respectively, with minor modifications. Distinctions between IVP protocols during the various embryo production steps are depicted in Table 1.

- In vitro maturation (IVM). COCs were in vitromatured in TCM-199 supplemented with $25.0 \mathrm{mM}$ $\mathrm{NaHCO}_{3}, 0.2 \mathrm{mM}$ pyruvic acid, $50 \mu \mathrm{g} / \mathrm{mL}$ gentamicin, $0.5 \mu \mathrm{g} / \mathrm{mL}$ FSH, $0.03 \mathrm{IU} / \mathrm{mL}$ hCG and heat inactivated estrous serum (Table 1) for $24 \mathrm{~h}$ at $39^{\circ} \mathrm{C}$ and $5 \% \mathrm{CO}_{2}$ in humidified air.

- In vitro fertilization (IVF). Frozen-thawed spermatozoa were segregated by swim-up in SpermTALP [25]. Capacitated sperm cells were added to Fert-TALP medium [25] at $10^{6}$ cells $/ \mathrm{mL}$ and co-cultured with COCs for $20 \mathrm{~h}$.

- In vitro culture (IVC). For Protocol 1, presumptive zygotes were cultured in modified SOF medium [6] at $39^{\circ} \mathrm{C}$ for $168 \mathrm{~h}$, under the conditions described in Table 1. Cleavage rates were recorded on Day 2 of development (IVF = Day 0). For IVC in Protocol 2, presumptive zygotes were incubated in SOFaaci medium [11] at $39^{\circ} \mathrm{C}$ in $5 \% \mathrm{CO}_{2}$ in humidified air. Cleavage rates were recorded at $24 \mathrm{~h}$ of IVC, and at this time, uncleaved structures were removed from the wells and embryos were further cultured, under controlled atmosphere (Table 1) for additional $144 \mathrm{~h}$ at $39^{\circ} \mathrm{C}$.

\begin{tabular}{ccccccccc}
\multicolumn{6}{c}{ Table 1. Major distinctions between protocols (Prot.) for bovine in vitro embryo production. } \\
\hline $\begin{array}{c}\text { IVP } \\
\text { Step }\end{array}$ & Prot. & E $_{2}$ & $\begin{array}{c}\text { Protein } \\
\text { source }\end{array}$ & Structures & $\begin{array}{c}\text { Media } \\
\text { volume }\end{array}$ & Media & $\begin{array}{c}\text { Oil } \\
\text { overlay }\end{array}$ & $\begin{array}{c}\text { O }_{2} \\
\text { Tension }\end{array}$ \\
\hline \multirow{2}{*}{ IVM } & 1 & Yes & $10 \%$ ECS & $15 \mathrm{COC}$ & $100 \mu \mathrm{L}$ & TCM 199 & Yes & $20 \%$ \\
& 2 & No & $10 \%$ EMS & $30-40 \mathrm{COC}$ & $400 \mu \mathrm{L}$ & & No & $20 \%$ \\
IVF & 1 & - & BSA & $15 \mathrm{COC}$ & $100 \mu \mathrm{L}$ & & Yes & $20 \%$ \\
& 2 & - & BSA & $30-40 \mathrm{COC}$ & $400 \mu \mathrm{L}$ & Fert-TALP & No & $20 \%$ \\
IVC & 1 & - & $10 \% \mathrm{ECS}$ & $20 \mathrm{Emb}$. & $80 \mu \mathrm{L}$ & SOF & Yes & $5 \% / 168 \mathrm{~h}$ \\
& 2 & - & $5 \% \mathrm{EMS}$ & $30-40 \mathrm{Emb}$. & $400 \mu \mathrm{L}$ & SOFaaci & Yes & $20 \% / 24 \mathrm{~h}$ \\
\end{tabular}




\section{Embryo selection}

At the end of the culture period $(168 \mathrm{~h}=$ Day

7 ), blastocyst rates were recorded and only embryos reaching the expanded blastocyst stage $(\geq 180 \mu \mathrm{m}$ diameter) and classified morphologically as grade 1-2 [10] were selected for the experiments. The basic medium (BM) for embryo maintenance, vitrification and warming was PBS supplemented with $10 \%$ fetal calf serum (FCS). Embryos from both protocols that did not shrink after exposure to BM for $5 \mathrm{~min}$ were randomly allocated either to the non-vitrified control sub-group or to the vitrified sub-group. Embryos identified as controls were maintained in $\mathrm{BM}$ on a warm stage at $39^{\circ} \mathrm{C}$ for approximately $60 \mathrm{~min}$, time required for the vitrification and warming of both vitrification sub-groups. Twelve replicates were carried out to standardize procedures and minimize experimental variations.

\section{Vitrification procedure}

Embryos were exposed for 5 to $10 \mathrm{~min}$ to BM $+3 \%$ ethylene glycol (EG) for the evaluation of their osmotic behavior [13] and to promote an additional cryoprotectant cell influx to attain cellular saturation prior to vitrification [24]. Embryos that did not fully reexpand after shrinkage were discarded from the study. The vitrification procedure was based on methods originally described by Vajta et al. [35] using hand-pulled glass micropipettes (GMP), with outer diameters of approximately $0.6 \mathrm{~mm}$, instead of plastic straws. GMPs containing vitrified embryos to be warmed for the in vitro development experiment were held vertically in a small plastic tube partially immersed in $\mathrm{LN}_{2}$, whereas GMPs containing vitrified embryos to be stored for their subsequent transfer to recipients (in vivo development experiment) were placed into pre-cooled and labeled $0.5 \mathrm{~mL}$ plastic straws [33], and stored in a $\mathrm{LN}_{2}$ tank.

\section{Warming and in straw cryoprotectant dilution procedures}

The warming procedure was based on the methods originally described by Isachenko et al. [12], using a warming solution (WS) composed of BM + $0.26 \mathrm{M}$ sucrose. Following warming and pre-dilution [12], the contents of the GMPs were transferred into a plastic straw loaded with WS. For the in vitro development experiment, each straw loaded with a single embryo was held horizontally for $10 \mathrm{~min}$ at RT; then, embryos were expelled into a dish containing BM. Subsequently, vitrified and the non-vitrified control em- bryos were transferred to $100 \mathrm{~mL}$ drops of SOFaaci supplemented with $5 \%(\mathrm{v} / \mathrm{v})$ of EMS, under oil, for additional $72 \mathrm{~h}$ of IVC for the determination of reexpansion and hatching rates. For the in vivo development experiment, each straw loaded with a single embryo was held horizontally for $5 \mathrm{~min}$, at RT, prior to the direct non-surgical single embryo transfer (ET) to synchronous ( $\pm 24 \mathrm{~h}$ ) recipient females. Pregnancy diagnosis was performed on Day 60 of gestation (53 days after ET) by rectal palpation.

\section{Statistical analysis}

Re-expansion, hatching and pregnancies rates were analyzed by the Chi-square test. Probability of $\mathrm{P}<0.05$ was considered statistically significant.

\section{RESULTS}

After twelve replications, cleavage rates were different $(\mathrm{P}=0.0002)$ between protocols. However, the number of expanded blastocysts on D7 was similar between groups (Table 2). Re-expansion rates of vitrified embryos did not differ $(\mathrm{P}>0.05)$ between protocols, but hatching rates of both vitrified and nonvitrified control embryos from Protocol 1 had a trend $(\mathrm{P}=0.0561)$ to be higher than embryos from Protocol 2 (Table 3). Embryo transfers after in-straw cryoprotectant dilution resulted in 4 (19\%) pregnancies per experimental group at 60 Days of gestation.

Table 2. Comparative embryo yield efficiency between two IVP protocols (12 replications).

\begin{tabular}{ccccc}
\hline Protocol & $\begin{array}{c}\text { IVC } \\
\mathbf{n}\end{array}$ & $\begin{array}{c}\text { Cleavage } \\
\mathbf{n}(\%)\end{array}$ & $\begin{array}{c}\text { Embryos } \\
\mathbf{D} 7 \mathbf{n}(\%)\end{array}$ & $\begin{array}{c}\text { Expanded } \\
\text { blastocysts } \\
\mathbf{n}(\%)\end{array}$ \\
\hline 1 & 2155 & $1491^{\mathrm{a}}(69.2)$ & $523^{\mathrm{a}}(24.7)$ & $253^{\mathrm{a}}(11.7)$ \\
2 & 2605 & $1931^{\mathrm{b}}(74.1)$ & $583^{\mathrm{a}}(22.4)$ & $279^{\mathrm{a}}(10.7)$ \\
\hline
\end{tabular}

Table 3. In vitro developmental rates of vitrified and nonvitrified (control) embryos produced by two different IVP protocols.

\begin{tabular}{|c|c|c|c|c|}
\hline \multirow{2}{*}{ Protocol } & \multicolumn{2}{|c|}{ Re-expansion at $24 \mathrm{~h}$} & \multicolumn{2}{|c|}{ Hatching at $72 \mathrm{~h}$} \\
\hline & vitrified & control & vitrified & control \\
\hline 1 & $\begin{array}{c}55 / 58 \\
(94.8 \%)\end{array}$ & - & $\begin{array}{c}44 / 58^{A} \\
(75.8 \%)\end{array}$ & $\begin{array}{c}48 / 60^{A} \\
(80.0 \%)\end{array}$ \\
\hline 2 & $\begin{array}{c}55 / 59 \\
(93.2 \%)\end{array}$ & - & $\begin{array}{c}35 / 59^{\mathrm{B}} \\
(59.3 \%)\end{array}$ & $\begin{array}{c}43 / 64^{\mathrm{B}} \\
(67.2 \%)\end{array}$ \\
\hline
\end{tabular}




\section{DISCUSSION}

The worldwide increase in the number of research groups adopting IVP technologies, along with the rise in its commercial applications, have tremendously diversified IVP procedures among different laboratories. Consequently, embryo production efficiencies between IVP protocols, or even laboratories, are very difficult to reconcile. In this study, embryo developmental rates were relatively similar between IVP protocols, despite differences regarding presence or absence of oil underlay and/or steroid hormone during IVM, or protein source, oocyte/embryo density, and media volume during the IVP steps.

The medium droplet method used in Protocol 1 was first introduced by Gwatkin [9] for mammalian embryo culture and still remains very popular for the IVP of mammalian embryos. Nevertheless, it is known that the use of oil overlay determines a high contacting surface/volume ratio with the culture medium, resulting in an interaction, and potential exchange, of lipophilic substances (e.g., estradiol, progesterone) between both fluids, which may cause changes in medium composition [36], affecting embryo development. In this view, our results corroborated with Xu et al. [38], in which the absence of oil overlay during bovine IVM showed better cleavage rates than the maturation in medium under oil (Table 2). Such differences could well be attributed to better IVM conditions under Protocol 2 (no oil overlay).

In addition, the use of larger numbers of oocytes [15] or medium volume during IVM may also be beneficial to maturation. However, despite the higher cleavage rate observed in Protocol 2, blastocyst rates were not different between IVP protocols. This effect could be associated with the embryo incubation in 5\% $\mathrm{CO}_{2}$ in air $\left(20 \% \mathrm{O}_{2}\right)$ during the first $24 \mathrm{~h}$ of IVC, which is in accordance with results by others [40]. This biphasic gas atmosphere procedure was used in Protocol 2 to avoid the excessive manipulation of the dish prior to cleavage rate evaluation and removal of uncleaved structures from the wells [30]. Yuan et al. [40] demonstrated that the IVC at $20 \% \mathrm{O}_{2}$ for $72 \mathrm{~h}$ compromised the subsequent zygote development, even if the $\mathrm{O}_{2}$ tension were lowered to $5 \%$ afterwards. In Protocol 1, the entire IVC period occurred under a low $\mathrm{O}_{2}$ tension (5\%), and in a higher embryo density [26] and serum concentration (10\% vs. 5\%) than Protocol 2. More serum in the medium provides more glucose levels and stimulates blastocysts development by accelerating the process of blastulation $[17,31,39]$. Despite these potential embryotrophic effects in Protocol 1, the use of EMS in Protocol 2 could also confer similar blastocyst yields, probably induced by embryotrophic factors (e.g., polyamine mitogenic factor) present in the equine serum [7]. The similar blastocyst rates observed between both IVP protocols showed compensatory differences during the distinct stages of the IVP process. These data are in accordance with the observation that embryo production is also dependent on the origin and quality of the oocytes $[15,28]$, in parallel to the IVP protocol.

During embryo selection by morphology and diameter, some embryos shrank upon exposure to PBS + FCS, despite medium isosmolarity. This osmotic behavior is thought to be an adjustment of the embryonic metabolic pathways to the abrupt change in substrate composition [8]. In this study, embryos that shrank in PBS or in a 3\% EG solution were discarded; only embryos capable of activating osmotic control mechanisms necessary to tolerate the cryopreservation process [13] were selected. Interestingly, in some replications of this study, part of the embryos in the control group did not hatch after IVC, despite the selection of early blastulation and higher diameter criteria to improve embryo selection [23]. The lower hatching rate in non-vitrified embryos appeared to characterize metabolic alterations not identified or detectable during the selection process.

In the vitrified groups, embryos from Protocol $1 \mathrm{had}$ a trend for a better hatching rate $\left(\mathrm{P}=0.0561, \mathrm{Chi}^{2}\right.$ test). However, this trend observed in the in vitro survival study was not confirmed in the in vivo studies after the transfer of embryos to synchronous recipients ( $\mathrm{P}>0.05)$. These results agree with Donnay et al. [4], i.e., that no correlation exists between hatching and pregnancy rates. The lack of correlation between in vitro and in vivo development could also be attributed to the influence of the IVC conditions in the hatching rates post-warming [27].

If in vitro-produced bovine embryos are to be fully utilized in practice, the warming procedure must be simple and efficient enough to allow embryos to be handled and transferred in a fashion as simple as artificial insemination with thawed semen. In this study, embryos were successfully vitrified employing handpulled glass micropipettes (GMP) instead of hand-pulled plastic straws [35]. The use of a tube with a larger ope- 
ning for the warming of vitrified samples [12] enhances the warming rate and facilitates the process when compared with the use of $0.25 \mathrm{~mL}$ straws [16,34]. In addition, the dilution of the cryoprotectant agents within plastic straws allowed embryos to be prepared, effectively and promptly, for direct transfer without the need of a stereomicroscope, which represents a considerable improvement and simplification for the direct transfer of bovine embryos vitrified into GMP or OPS.

The vitrification procedure usually results in cellular and subcellular damage, most of which are gradually restored over a $24 \mathrm{~h}$ period [32]. A reduction in the inner cell mass and trophectodermal cell number in vitrified embryos [14] might be one of the possible causes of placentary alterations, which may be associated with lower gestation rates after in vitro embryo manipulations [2]. In this study, pregnancy rates on Day 60 for both protocols were lower than those reported by Lewis et al. [16]. However, those authors transferred two embryos per recipient, and performed the pregnancy diagnoses 40 days after transfer, which should confer higher pregnancy rates than the data reported in this study. The transfer of a single embryo per recipient and the pregnancy diagnosis on Day 60 were chosen for practical and economical reasons, since the highest rates of embryonic and fetal losses in IVP embryos are known to occur between Days 30 and 44 of pregnancy [2]. After this period, pregnancy rates will reflect more closely the effectiveness of each IVP protocol. This fact highlights the importance of a late ges- tation diagnosis, which is of economical importance to production per se, since losses after Day 60 of pregnancy do not appear to be higher in IVP pregnancies than controls [2].

\section{CONCLUSIONS}

Major variations in IVP protocols in this study included oil overlay and/or estradiol supplementation, protein source, oocyte/zygote density, medium volume, and culture atmosphere. Such differences in IVP protocols, under the same laboratorial conditions, did not affect embryo development to the blastocyst stage, the cryotolerance of expanded blastocysts, and pregnancy rates of vitrified embryos following transfer to synchronous recipients.

Further work is required to determine the effect of additional steps in different protocols on embryo yield, quality and cryotolerance. However, judging from these in vitro and in vivo experiments, the vitrification of embryos in hand-pulled glass micropipettes, combined with alternative warming and in-straw cryoprotectant dilution procedures, was proven effective for the direct transfer of IVP bovine blastocysts under field conditions, which has an important role in the practical implications for IVP research and its commercial application.

Acknowledgments. The authors thank the Coudelaria de Rincão (Brazilian Army) for making recipient females available for embryo transfer. Vieira, F. Forell, C. Feltrin and L.C. Santos were supported by fellowships from Brazilian National Science and Technology Development Council (CNPq).

\section{REFERENCES}

1 Abe H., Yamashita S., Satoh T. \& Hoshi H. 2002. Accumulation of cytoplasmic lipid droplets in bovine embryos and cryotolerance of embryos developed in different culture systems using serum-free or serum-containing media. Molecular Reproduction Development. 61: 57-66.

2 Bertolini M. \& Anderson G.B. 2002. The placenta as a contributor to production of large calves. Theriogenology. 57: 181-187.

3 Cho S.K., Cho S.G., Bae I.H., Park C.S. \& Kong I.K. 2002. Improvement in post-thaw viability of in vitro-produced bovine blastocysts vitrified by glass micropipette (GMP). Animal Reproduction Science. 73: 151-158.

4 Donnay I., Auquier Ph., Kaidi S., Carolan C., Lonergan P., Mermillod P. \& Massip A. 1998. Vitrification of in vitro produced bovine blastocysts: Methodological studies and developmental capacity. Animal Reproduction Science. 52: 93-104.

5 Fair T., Lonergan P., Dinnyés A., Cottell D.C., Hyttel P., Ward F.A. \& Boland M.P. 2001. Ultrastructure of bovine blastocysts following cryopreservation: Effect of method of blastocyst production. Molecular Reproduction Development. 58: 186-195.

6 Forell F., Oliveira A.T.D., Lopes R.F.F. \& Rodrigues J.L. 2004. Produção in vitro de embriões bovinos em meio SOF com SVE ou BSA. Brazilian Journal of Veterinary Research and animal Science. 41: 396-403.

7 Freshney I.R. 2000. Media. In: Freshney I.R. (Ed). Culture of animal cells: a manual of basic technique. 4th edn. New York: Wiley-Liss, pp.89-104.

8 Gandhi A.P., Lane M., Gardner D.K. \& Krisher R.L. 2000. A single medium supports development of bovine embryos throughout maturation, fertilization and culture. Human Reproduction. 15: 395-401. 
9 Gwatkin R.B.L. 1963. Effect of viruses on early mammalian development I. Action of meningo encephalitis virus on mouse ova cultivated in vitro. Proceendings of the National Academy of Sciences - USA. 50: 576-581.

10 Hasler J.F., Henderson W.B., Hurtgen P.J., Jin Z.Q., McCauley A.D., Mower S.A., Neely B., Shuey L.S., Stokes J.E. \& Trimmer S.A. 1995. Production, freezing and transfer of bovine IVF embryos and subsequent calving results. Theriogenology. 43: 141-152.

11 Holm P., Booth P.J., Schmidt M.H., Greve T. \& Callesen H. 1999. High bovine blastocyst development in a static in vitro production system using SOFaa medium supplemented with Sodium citrate and Myo-inositol with or without serum-proteins. Theriogenology. 52: 863-700.

12 Isachenko V., Alabart J.L., Dattena M., Nawroth F., Cappai P., Isachenko E., Cocero M.J., Olivera J., Roche A., Accardo C., Krivokharchenko A. \& Folch J. 2003. New technology for vitrification and field (microscope-free) warming and transfer of small ruminant embryos. Theriogenology. 59: 1209-1218.

13 Kaidi S., Donnay I., Lambert P., Dessy F. \& Massip A. 2000. Osmotic behavior of in vitro produced bovine blastocysts in cryoprotectant solutions as a potential predictive test of survival. Cryobiology. 41: 106-115.

14 Kaidi S., Bernard S., Massip A., Dessy F. \& Donnay I. 2001. Effect of conventional controlled-rate freezing and vitrification on morphology and metabolism of bovine blastocysts produced in vitro. Biology of Reproduction. 65: 1127-1134.

15 Khurana N.K. \& Niemann H. 2000. Effects of oocyte quality, oxygen tension, embryo density, cumulus cells and energy substrates on cleavage and morula/blastocyst formation of bovine embryos. Theriogenology. 54: 741-756.

16 Lewis I.M., Lane M.W. \& Vajta G. 1999. Pregnancy rates following transfer of in vitro produced bovine embryos vitrified by open pulled straw (OPS) method. Theriogenology. 51: 168.

17 Lonergan P., O’Kearney-Flyn M., Boland M.P. 1999. Effect of protein supplementation and presence of an antioxidant on the development of bovine zygotes in synthetic oviduct fluid medium under high or low oxygen tension. Theriogenology. 51: $1565-1576$.

18 Lonergan P., Rizos D., Ward F. \& Boland M.P. 2001. Factors influencing oocyte and embryo quality in cattle. Reproduction Nutrition Development. 41: 427-437.

19 Lonergan P., Rizos D., Gutièrrez-Ádan T.H.E., Fair T. \& Boland M.P. 2003. Oocyte and embryo quality: effect of origin, culture conditions and gene expression patterns. Reproduction Domestic Animals. 38: 259-267.

20 Mezzalira A., Vieira A.D., Cruz F.B., Barbieri D.P. \& Damiani J.C. 2002. Vitrificação de ovócitos bovinos com a utilização de micropipetas de vidro ou palhetas estiradas. Revista de Ciências Agroveterinárias. 1: 108-114.

21 Nagano M., Takahashi Y. \& Katagiri S. 1999. The efficacy of the water purification system with an ultra violet lamp and ultrafilter goes the preparation of bovine embryo culture it measured. Journal of Reproduction Development. 45: $239-242$.

22 Nagao Y., Saeki K., Hoshi M., Takahashi Y. \& Kanagawa H. 1995. Effects of water quality on in vitro fertilization and development of bovine oocytes in protein-free medium. Theriogenology. 44: 433-444.

23 Nedambale T.L., Dinnyés A., Yang X. \& Tian X.C. 2004. Bovine blastocyst development in vitro: Timing, sex, and viability following vitrification. Biology of Reproduction. 71: 1671-1676.

24 Papis K., Shimizu M. \& Izaike Y. 1999. A highly efficient modified vitrification method, for day 3 in vitro produced bovine embryos. Cryo-Letters. 20: 203-206.

25 Parrish J.J., Susko-Parrish J., Winer M.A. \& First N.L. 1988. Capacitation of bovine sperm by heparin. Biology of Reproduction. 38: 1171-1180.

26 Reichenbach H.D. \& Weppert M. 2002. Effect of group size on the development of bovine embryos in vitro cultured in different systems. Theriogenology. 57: 525.

27 Rizos D., Ward F., Boland M.P. \& Lonergan P. 2001. Effect of culture system on the yield and quality of bovine blastocyst as assessed by survival after vitrification. Theriogenoloy. 56: 1-16.

28 Rizos D., Ward F., Duffy P., Boland M.P. \& Lonergan P. 2002. Consequences of bovine oocyte maturation, fertilization or early embryo development in vitro versus in vivo: Implications for blastocyst yield and blastocyst quality. Molecular Reproduction Development. 61: 234-248.

29 Rodrigues J.L., Ullah N., Döpke H-H. \& Niemann H. 1995. Viability of IVMFC bovine embryos following freezing in 3,6M ethylene glycol as cryoprotective additive. ARS Veterinária. 11: 60-67.

30 Salahuddin S., Ookutsu S., Goto K., Nakanishi Y. \& Nagata Y. 1995. Effects of embryo density and co-culture of unfertilized oocytes on embryonic development of in vitro fertilized mouse embryos. Human Reproduction. 10: $2382-2385$. 
31 Thompson J.G., Allen N.W., McGowan L.T., Bell A.C.S., Lambert M.G. \& Tervit H.R. 1998. Effect of delayed supplementation of foetal calf serum to culture medium on bovine embryo development in vitro and following transfer. Theriogenology. 49: 1239-1249.

32 Vajta G., Hyttel P. \& Callesen H. 1997. Morphological changes of in-vitro-produced bovine blastocysts after vitrification, instraw direct rehydration, and culture. Molecular Reproduction Development. 48: 9-17.

33 Vajta G., Lewis I.M., Kuwayama M., Greve T. \& Callesen H. 1998. Sterile application of open pulled straw (OPS) vitrification method. Cryo-Letters. 19: 389-392.

34 Vajta G., Murphy C.N., Macháty Z., Prather R.S., Greve T. \& Callesen H. 1999. In-straw dilution of bovine blastocysts after vitrification with the open-pulled straw method. Veterinary Records. 144: 180-181.

35 Vajta G., Rindom N., Peura T.T., Holm P., Greve T. \& Callesen H. 1999. The effect of media, serum and temperature on in vitro survival of bovine blastocysts after open pulled straw (OPS) vitrification. Theriogenology. 52: 939-948.

36 Van Soom A., Mahmoudzadeh A.R., ChristopheA., Ysebaert M.T. \& de Kruif A. 2001. Silicone oil used in microdrop culture can affect bovine embryonic development and freezability. Reproduction Domestic Animals. 36: 169-176.

37 Vieira A.D., Mezzalira A., Barbieri D.P., Lehmkuhl R.C., Rubin M.I.B. \& Vajta G. 2002. Calves born after open pulled straw vitrification of immature bovine oocytes. Cryobiology. 45: 91-94.

38 Xu K.P., Høier R. \& Greve T. 1988. Dynamic changes of estradiol and progesterone concentrations during in vitro oocyte maturation in cattle. Theriogenology. 30: 245-255.

39 Yoshioka K., Othman A.M., Taniguchi T., Yamaka H. \& Sekikawa K. 1997. Differential patterns of blastulation in bovine morula cultured in synthetic oviduct fluid medium containing FCS or BSA. Theriogenology. 48: 997-1006.

40 Yuan Y.Q., Van Soom A., Coopman F.O.J., Mintiens K., Boerjan M.L., Van Zeveren A., Kruif A. de. \& Peelman L.J. 2003. Influence of oxygen tension on apoptosis and hatching in bovine embryos cultured in vitro. Theriogenology. 59: $1585-1596$. 